\title{
Structural and Spectroscopic Properties of Two New Isostructural Complexes of Lapacholate with Cobalt and Copper
}

\author{
R. A. Farfán, ${ }^{1}$ J. A. Espíndola, ${ }^{1}$ M. I. Gomez, ${ }^{2}$ M. C. L. de Jiménez, ${ }^{2}$ \\ M. A. Martínez, ${ }^{2}$ O. E. Piro, ${ }^{3}$ and E. E. Castellano ${ }^{4}$ \\ ${ }^{1}$ Facultad de Ciencias Exactas, Universidad Nacional de Salta, Avenida Bolivia 5150, 4400 Salta, Argentina \\ ${ }^{2}$ Facultad de Bioquímica, Química y Farmacia, Universidad Nacional de Tucumán, Ayacucho 491, 4000 Tucumán, Argentina \\ ${ }^{3}$ Departamento de Física, Facultad de Ciencias Exactas, Universidad Nacional de La Plata and Institute IFLP \\ (CONICET-CCT La Plata), C. C. 67, 1900 La Plata, Argentina \\ ${ }^{4}$ Instituto de Física de São Carlos, Universidade de São Paulo, C.P. 369, 13560 São Carlos, SP, Brazil
}

Correspondence should be addressed to R. A. Farfán, raf@unsa.edu.ar

Received 18 November 2011; Revised 24 January 2012; Accepted 24 February 2012

Academic Editor: Peter Baran

Copyright ( 2012 R. A. Farfán et al. This is an open access article distributed under the Creative Commons Attribution License, which permits unrestricted use, distribution, and reproduction in any medium, provided the original work is properly cited.

The molecular structures of two isostructural complexes of lapacholate (Lap) anion and dimethylformamide (DMF), $\mathrm{M}(\mathrm{Lap})_{2}(\mathrm{DMF})_{2}$ with $\mathrm{M}$ : Co Cu, were determined by X-ray diffraction methods. The substances crystallize in the triclinic space group $P \overline{1}$ with one molecule per unit cell and cell constants $a=7.7591(3), b=10.3560(3), c=11.2224(4) \AA, \alpha=95.110(2)$, $\beta=94.310(2)$, and $\gamma=107.704(2)^{\circ}$ for the Co complex and $a=7.9308(2), b=10.0033(4), c=10.7508(4), \alpha=97.387(2)$, $\beta=93.621(2)$, and $\gamma=103.980(2)^{\circ}$ for the $\mathrm{Cu}$ complex. The structures were solved from $2933(\mathrm{Co})$ and $2888(\mathrm{Cu})$ reflections with $I>2 \sigma(I)$ and refined by full matrix least squares to agreement $R_{1}$-factors of $0.041(\mathrm{Co})$ and $0.033(\mathrm{Cu})$. The metal M(II) ion is sited on a crystallographic inversion center in a $\mathrm{MO}_{6}$ distorted octahedral environment. This ion is coordinated equatorially to two lapacholate anions through their adjacent carbonyl and phenol oxygen atoms [M-O bond distances of 2.134(1) and 2.008(1) $\AA$ (Co) and 2.301(1) and 1.914(1) $\AA(\mathrm{Cu})$ ] and axially to two DMF molecules through oxygen atoms [M-O bond lengths of 2.143(1) $\AA(\mathrm{Co})$ and 2.069(1) $\AA(\mathrm{Cu})]$. The solid state IR transmittance and solution electronic absorption spectra of both Co and Cu compounds are also reported and compared to each other and to the corresponding spectra of other members of the lapacholate metal family of complexes.

\section{Introduction}

Lapachol (LapH), [2-hydroxy-3(3-methyl-2-butenyl)-1,4naphthoquinone] is a yellow pigment present in several plant species, including the Lapacho tree Tabebuia ipe (shredded wood) from which it is extracted. This extract is also used as alternative medicine for different illness such as cancer, Chagas, and various skin diseases [1-6]. A tea extract from the inner bark of the Lapacho tree has been used as a folk remedy against many diseases in South America since the time of the Incas [7]. Lapachol presents pharmacological activity similar to acetonaphthonates, flavonates, and hydroxypyronates [8]. Several patents involving pharmaceutical applications of Lapachol have been filed in the last few years; for example, in 2008 alone there were granted 13 related patents [7]. The quest for improving this activity prompted renewed work during the last 10 years on the synthesis, physicochemical characterization, and pharmacological properties of Lapachol complexes with transition metal ions, including the $\mathrm{Zn}$, $\mathrm{Ni}$, and Mn lapacholates [7, 9, 10].

In alkaline medium, LapH loses a proton. This gives rise to a lapacholate anion (Lap) and turns into a bidentate ligand (Lap) to divalent metal ions through its phenolic and quinonic oxygen atoms located at positions 1 and 2 (see Scheme 1).

We present here the synthesis, characterization and the crystal structure of two new isostructural complexes of $\mathrm{Co}(\mathrm{II})$ and $\mathrm{Cu}(\mathrm{II})$ with $\mathrm{LapH}$ and $\mathrm{DMF}$ as ligands of formula $\left[\mathrm{M}(\mathrm{Lap})_{2}(\mathrm{DMF})_{2}\right], \mathrm{M}: \mathrm{Co}, \mathrm{Cu}$. 


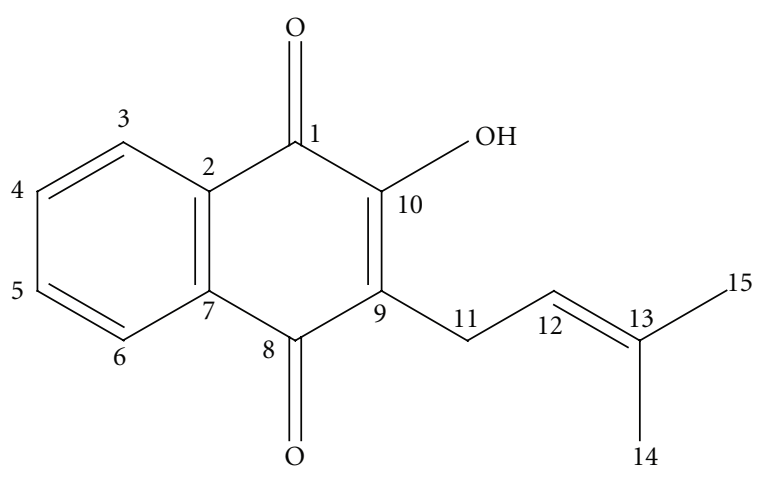

Scheme 1: Molecular structure of Lapachol with carbon labeling as in the X-ray study.

\section{Experimental}

\subsection{Preparation}

Co Complex. This compound was prepared at room temperature, by mixing $0.99 \mathrm{~g}$ of Lapachol in $50 \mathrm{~mL}$ of dimethylformamide (DMF), solution of concentration $0.08 \mathrm{M}$, with $0.74 \mathrm{~g}$ of cobalt(II) acetate tetrahydrate in $100 \mathrm{~mL}$ of water $(0.03 \mathrm{M})$. The precipitate, with a yield of $78.6 \%$, was separated by filtration, washed with water, dried, and redissolved in dimethylformamide. Single crystals adequate for structural X-ray diffraction were obtained by slow evaporation of the solvent.

Cu Complex. $0.54 \mathrm{~g}$ of Lapachol in $20 \mathrm{~mL}$ of DMF $(0.1 \mathrm{M})$ was added to a hot $\left(60^{\circ} \mathrm{C}\right)$ solution of $0.56 \mathrm{~g}$ of copper(II) acetate in $50 \mathrm{~mL}$ of water $(0,06 \mathrm{M})$. The resulting solution was stirred and kept at $60^{\circ} \mathrm{C}$ during few minutes and then left at room temperature. The precipitate obtained, with a yield of $64.9 \%$, was filtered out from the solution which was then allowed to evaporate until the appearance of single crystals. These were separated by filtration, washed with water, and then dried.

Lapachol was extracted with chloroform from the sawdust of "Lapacho" (Tabebuia ipé) and purified with absolute alcohol.

2.2. Chemical Analysis. The Lapachol content in both complexes was determined following the procedure described in [9] by measuring the ligand electronic absorption maxima at 330 and $390 \mathrm{~nm}\left(\varepsilon_{330}=2.8 \times 10^{3} \mathrm{~cm}^{-1}\right) \mathrm{M}^{-1}$ and $\left.\varepsilon_{390}=1.4 \times 10^{3} \mathrm{~cm}^{-1} \mathrm{M}^{-1}\right)$ [8]. Cobalt and copper content were determined by atomic absorption with a GBC 904 spectrophotometer.

2.3. X-ray Diffraction Data. The X-ray measurements were performed on an Enraf-Nonius Kappa-CCD diffractometer with graphite-monochromated $\operatorname{MoK} \alpha(\lambda=0.71073 \AA)$ radiation. Diffraction data were collected $(\varphi$ and $\omega$ scans with $\kappa$-offsets) with COLLECT [11]. Integration, scaling, and reduction of the diffraction intensities were performed with HKL DENZO-SCALEPACK [12] suite of programs. The data for the Co complex were corrected numerically for absorption effects with PLATON [13]. No absorption correction was applied to the $\mathrm{Cu}$ complex as the linear absorption coefficient times the largest crystal size was 0.116 . The unit cell parameters were obtained by least-squares refinement based on the angular settings for all collected reflections using HKL SCALEPACK [12]. The structures were solved by direct methods with SHELXS-97 [14] and the molecular model refined by full-matrix least-squares procedure on $F^{2}$ with SHELXL-97 [15]. The $\mathrm{H}$-atoms were positioned stereochemically and refined with the riding model. The locations of methyl hydrogen atoms were optimized during the refinement procedure by treating them as rigid bodies which were allowed to rotate around the corresponding C$\mathrm{C}$ bond. Crystal data and refinement results are summarized in Table 1. Full crystal structure data have been deposited at the Cambridge Crystallographic Data Centre under reference codes CCDC 846042 (Co complex) and CCDC 846043 (Cu complex). Enquiries for data can be directed to: Cambridge Crystallographic Data Centre, 12 Union Road, Cambridge, UK, CB2 1EZ or (e-mail) deposit@ccdc.cam.ac.uk or (fax) +44 (0) 1223336033 .

2.4. Spectra. Infrared transmittance spectra from 4000 to $400 \mathrm{~cm}^{-1}$ region were collected at a resolution of $4 \mathrm{~cm}^{-1}$ on KBr-sandwiched samples with a Perkin Elmer GX FTIR instrument. The electronic spectra (UV-Vis) of both solutions of DMF samples were run on a double-beam GBC 918 spectrophotometer.

2.5. Thermogravimetric Analysis. TGA was performed under flowing oxygen $(50 \mathrm{~mL} / \mathrm{min})$ with a Shimadzu TGA-50 instrument at a heating rate of $5^{\circ} \mathrm{C} / \mathrm{min}$ from room temperature to $500^{\circ} \mathrm{C}$.

\section{Results}

3.1. Physical Properties. The dark red crystals of both complexes were stable in ambient conditions. They are soluble in DMF, ethanol, and ether, less soluble in benzene, and insoluble in water.

3.2. Analytical Results. Elemental analyses: for the Co complex, Anal Calcd (\%). Co: 8.59; LapH: 70.35. Found (\%) Co: $8.52 \pm 0.3$; LapH: 70.66. For the Cu complex, anal Calcd (\%) Cu: 9.20; LapH: 70.19. Found (\%) Cu: $9.14 \pm 0.08$; LapH: 69.86 .

\section{Discussion}

4.1. Structural Results. An ORTEP [16] drawing of the copper complex is shown in Figure 1, and corresponding bond distances and angles around the metal ion for both complexes are in Table 2. The metal ions are sited on a crystallographic inversion center in a distorted octahedral environment, equatorially coordinated to two symmetry-related lapacholate anions acting as bidentate ligands through their 


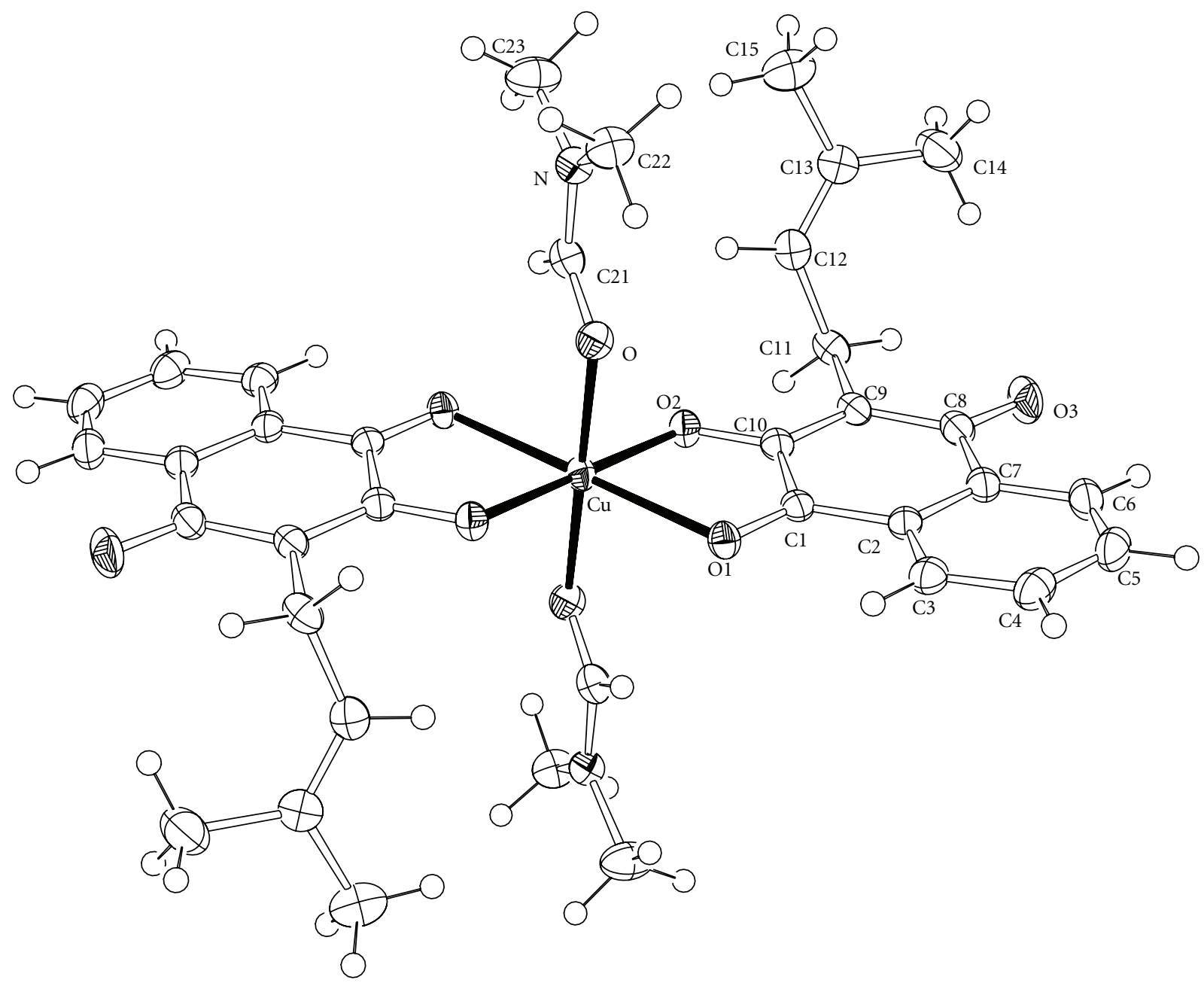

Figure 1: Drawing of $\mathrm{Cu}(\mathrm{Lap})_{2}(\mathrm{DMF})_{2}$ complex showing the labeling of the non-H atoms and their displacement ellipsoids at the $50 \%$ probability level. $\mathrm{Cu}(\mathrm{II})$-ligand bonds are indicated by dark lines.

adjacent carbonyl (O1) and phenol (O2) oxygen atoms [M$\mathrm{O}$ bond distances of 2.134(1) and 2.008(1) $\AA$ for the Co complex and 2.301(1) and 1.914(1) $\AA$ for the $\mathrm{Cu}$ one]. The axial positions are occupied by the oxygen atoms of a pair of inversion-related DMF molecules [M-O distances of 2.143(1) and 2.069(1) $\AA$ for the $\mathrm{Co}$ and Cu complexes, resp.]. Cis $\mathrm{O}-\mathrm{M}-\mathrm{O}$ angles in the $\mathrm{MO}_{6}$ core are in the range from $79.38(5)$ to $100.62(5)^{\circ}$ for $\mathrm{M}=\mathrm{Co}$ and from 78.56(5) to $101.44(5)^{\circ}$ for $\mathrm{M}=\mathrm{Cu}$. In both complexes, the lapacholate ligand is planar ( rms deviation of fitted atoms from the corresponding least-squares planes are less than $0.065 \AA$ ).

The molecular structure of $\mathrm{M}(\mathrm{Lap})_{2}(\mathrm{DMF})_{2}$ (M: Co, $\mathrm{Cu}$ ) is closely related to other metal complexes with a pair of equatorially coordinated lapacholate ions. These include the $\mathrm{Zn}(\mathrm{Lap})_{2}(\mathrm{EtOH})_{2}$ center symmetric complex, where the EtOH ligands coordinate axially to the metal [9] and also $\mathrm{Ni}(\mathrm{Lap})_{2}(\mathrm{DMF})\left(\mathrm{H}_{2} \mathrm{O}\right)$ where two nearly parallel lapacholate ions cis-coordinate the $\mathrm{Ni}(\mathrm{II})$ ion and the octahedral axial positions are occupied by DMF and water molecules [10]. The versatility of lapacholate anions to coordinate transition metal ions is shown by the related $\mathrm{M}(\mathrm{Lap})_{2}(\mathrm{DMF})\left(\mathrm{H}_{2} \mathrm{O}\right)$, $\mathrm{M}$ :
Co, $\mathrm{Zn}$ isostructural complexes. Here the $\mathrm{M}(\mathrm{II})$ ion is also in a distorted octahedral environment, but now coordinated by two nearly orthogonal (cis) lapacholate anions with DMF and water molecules completing the octahedral coordination at cis-positions to each other [3]. A similar cis coordination of near perpendicular lapacholates to metal is observed in the $\mathrm{Cu}(\mathrm{Lap}) 2 \mathrm{bpy}$, where the bipyridine molecule bridges the remaining cis-positions acting as a bidentate ligand though their $\mathrm{N}$-atoms [17]. Also $\left[\mathrm{Mn}(\mathrm{Lap})_{2}\right]_{n}$ shows near cis orthogonal lapacholate ions acting as bidentate ligands to $\mathrm{Mn}(\mathrm{II})$ ion through the orthocarbonyl and phenol oxygen atoms, but here the distorted octahedral coordination around the metal is completed by the para carbonyl oxygen of two neighboring complexes, giving rise to a polymeric arrangement in the lattice [7].

4.2. IR Spectra. The IR spectra of Figure 2 show that both complexes exhibit the same transmittance profile as others studied complexes of lapacholate $[10,18]$. The broadband centered at $3369 \mathrm{~cm}^{-1}(\mathrm{Co})$ and $3448 \mathrm{~cm}^{-1}(\mathrm{Cu})$ indicates the presence of moisture in the $\mathrm{KBr}$ disk that supports the 
TABle 1: Crystal data and structure solution methods and refinement results for $\mathrm{M}(\mathrm{Lap})_{2}(\mathrm{DMF})_{2}(\mathrm{M}: \mathrm{Co}, \mathrm{Cu})$ complexes.

\begin{tabular}{|c|c|c|}
\hline & $\mathrm{Co}(\mathrm{Lap})_{2}(\mathrm{DMF})_{2}$ & $\mathrm{Cu}(\mathrm{Lap})_{2}(\mathrm{DMF})_{2}$ \\
\hline Empirical formula & $\mathrm{C}_{36} \mathrm{H}_{40} \mathrm{CoN}_{2} \mathrm{O}_{8}$ & $\mathrm{C}_{36} \mathrm{H}_{40} \mathrm{CuN}_{2} \mathrm{O}_{8}$ \\
\hline Formula weight & 687.63 & 692.24 \\
\hline Temperature $\left({ }^{\circ} \mathrm{K}\right)$ & $296(2)$ & $120(2)$ \\
\hline Wavelength $(\AA)$ & 0.71 & 0.73 \\
\hline $\begin{array}{l}\text { Crystal system, } \\
\text { space group }\end{array}$ & \multicolumn{2}{|c|}{ Triclinic, $P-1(\# 2)$} \\
\hline \multicolumn{3}{|l|}{$\begin{array}{l}\text { Unit cell } \\
\text { dimensions }\end{array}$} \\
\hline$a(\AA)$ & $7.7591(3)$ & $7.9308(2)$ \\
\hline$b(\AA)$ & $10.3560(3)$ & $10.0033(4)$ \\
\hline$c(\AA)$ & $11.2224(4)$ & $10.7508(4)$ \\
\hline$\alpha\left(^{\circ}\right)$ & $95.110(2)$ & $97.387(2)$ \\
\hline$\beta\left(^{\circ}\right)$ & $94.310(2)$ & $93.621(2)$ \\
\hline$\gamma\left({ }^{\circ}\right)$ & $107.704(2)$ & $103.980(2)$ \\
\hline Volume $\left(\AA^{3}\right)$ & $850.65(5)$ & $816.83(5)$ \\
\hline $\begin{array}{l}\mathrm{Z} \text {, calculated } \\
\text { density }\left(\mathrm{Mg} / \mathrm{m}^{3}\right)\end{array}$ & $1,1.342$ & $1,1.407$ \\
\hline $\begin{array}{l}\text { Absorption } \\
\text { coefficient }\left(\mathrm{mm}^{1}\right)\end{array}$ & 0.558 & 0.725 \\
\hline$F(000)$ & 361 & 363 \\
\hline Crystal size (mm) & $0.32 \times 0.19 \times 0.10$ & $0.16 \times 0.12 \times 0.06$ \\
\hline Crystal color/shape & dark red/prism & dark red/fragment \\
\hline $\begin{array}{l}9 \text {-range for data } \\
\text { collection }\left(^{\circ}\right)\end{array}$ & 2.60 to 26.00 & 2.64 to 26.00 \\
\hline Index ranges & $\begin{array}{l}-9 \leq h \leq 9 \\
-12 \leq k \leq 12 \\
-13 \leq l \leq 13\end{array}$ & $\begin{array}{l}-9 \leq h \leq 9 \\
-12 \leq k \leq 12 \\
-13 \leq l \leq 13\end{array}$ \\
\hline $\begin{array}{l}\text { Reflections } \\
\text { collected/unique }\end{array}$ & $\begin{array}{l}11610 / 3342[R(\mathrm{int}) \\
=0.0656]\end{array}$ & $\begin{array}{l}14328 / 3210[R(\text { int }) \\
=0.0482]\end{array}$ \\
\hline $\begin{array}{l}\text { Completeness to } \\
\vartheta=26.00^{\circ}\end{array}$ & $99.6(\%)$ & $99.8 \%$ \\
\hline $\begin{array}{l}\text { Observed } \\
\text { reflections } \\
{[I>2 \sigma(I)]}\end{array}$ & 2933 & 2888 \\
\hline $\begin{array}{l}\text { Max. and min. } \\
\text { transmission }\end{array}$ & 0.9447 and 0.8429 & 0.9578 and 0.8929 \\
\hline $\begin{array}{l}\text { Data/restraints/ } \\
\text { parameters }\end{array}$ & $3342 / 0 / 218$ & $3210 / 0 / 218$ \\
\hline $\begin{array}{l}\text { Goodness of fit on } \\
F^{2}\end{array}$ & 1,043 & 1.053 \\
\hline $\begin{array}{l}\text { Final } R \\
\text { indices }^{\mathrm{a}}[I> \\
2 \sigma(I)]\end{array}$ & $\begin{array}{l}R_{1}=0.0411 \\
w R_{2}=0.1028\end{array}$ & $\begin{array}{l}R_{1}=0.0330 \\
w R_{2}=0.0784\end{array}$ \\
\hline$R$ indices (all data) & $\begin{array}{l}R_{1}=0.0517 \\
w R_{2}=0.1077\end{array}$ & $\begin{array}{l}R_{1}=0.0396 \\
w R_{2}=0.0820\end{array}$ \\
\hline $\begin{array}{l}\text { Largest peak and } \\
\text { hole }\end{array}$ & $\begin{array}{l}0.503 \text { and } \\
-0.427 \mathrm{e} \cdot \AA^{3}\end{array}$ & 0.286 and -0.607 \\
\hline
\end{tabular}

sample and therefore it will not be further discussed. In the $2800-3000 \mathrm{~cm}^{-1}$ spectral range there appear bands due
TABLe 2: Bond lengths $[\AA]$ and angles $\left[^{\circ}\right]$ around the metal ions in $\mathrm{M}(\mathrm{Lap})_{2}(\mathrm{DMF})_{2}, \mathrm{M}: \mathrm{Co}, \mathrm{Cu}$.

\begin{tabular}{lccc}
\hline \multicolumn{4}{c}{ Bond distances } \\
\hline $\mathrm{CO}-\mathrm{O}(2)$ & $2.008(1)$ & $\mathrm{Cu}-\mathrm{O}(2)$ & $1.914(1)$ \\
$\mathrm{CO}-\mathrm{O}(1)$ & $2.134(1)$ & $\mathrm{Cu}-\mathrm{O}(1)$ & $2.301(1)$ \\
$\mathrm{CO}-\mathrm{O}$ & $2.143(1)$ & $\mathrm{Cu}-\mathrm{O}$ & $2.069(1)$ \\
\hline \multicolumn{4}{c}{ Bond angles } \\
\hline $\mathrm{O}(2)-\mathrm{CO}-\mathrm{O}\left(1^{\prime}\right)$ & $100.62(5)$ & $\mathrm{O}(2)-\mathrm{Cu}-\mathrm{O}\left(1^{\prime}\right)$ & $101.44(5)$ \\
$\mathrm{O}(2)-\mathrm{CO}-\mathrm{O}(1)$ & $79.38(5)$ & $\mathrm{O}(2)-\mathrm{Cu}-\mathrm{O}(1)$ & $78.56(5)$ \\
$\mathrm{O}(2)-\mathrm{CO}-\mathrm{O}^{\prime}$ & $91.18(6)$ & $\mathrm{O}(2)-\mathrm{Cu}-\mathrm{O}^{\prime}$ & $90.03(5)$ \\
$\mathrm{O}(1)-\mathrm{CO}-\mathrm{O}^{\prime}$ & $88.24(5)$ & $\mathrm{O}(1)-\mathrm{Cu}-\mathrm{O}^{\prime}$ & $90.71(5)$ \\
$\mathrm{O}(2)-\mathrm{CO}-\mathrm{O}$ & $88.82(6)$ & $\mathrm{O}(2)-\mathrm{Cu}-\mathrm{O}$ & $89.97(5)$ \\
$\mathrm{O}(1)-\mathrm{CO}-\mathrm{O}$ & $91.76(6)$ & $\mathrm{O}(1)-\mathrm{Cu}-\mathrm{O}$ & $89.29(5)$ \\
\hline
\end{tabular}

Primed atoms are related to unprimed ones through the inversion symmetry operation: $-x,-y,-z$.

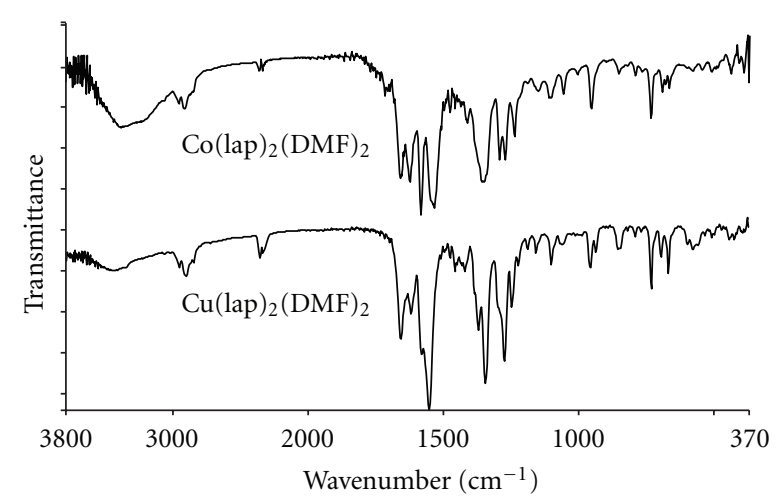

Figure 2

to $\mathrm{CH}$ stretching of the $\mathrm{CH}-\mathrm{CH}, \mathrm{CH}_{2}$, and $\mathrm{CH}_{3}$ groups. The stretching mode of noncoordinated to metal C8-O3 group appears at $1585 \mathrm{~cm}^{-1}(\mathrm{Co})$ and $1582 \mathrm{~cm}^{-1}(\mathrm{Cu})$, and stretching mode of the quinonic $\mathrm{CO}$ group (C1-O1) coordinated to the metal appears at $1630 \mathrm{~cm}^{-1}$ (Co) and $1621 \mathrm{~cm}^{-1}(\mathrm{Cu})$. These bands are red-shifted with respect to the corresponding bands of uncomplexed lapachol [19] at 1660 and $1640 \mathrm{~cm}^{-1}$, upon coordination to the metal and the resonance between the para- and orthonaphthoquinone forms that involves those carbonyl groups and the noncoordinated, C8-O3, hydrogen bonded (shifts from 1640 to 1585 and $1582 \mathrm{~cm}^{-1}$, resp.). In the region between 1620 and $1660 \mathrm{~cm}^{-1}$, overlapping bands appear that can be assigned to CO and DMF stretching modes [20]. The bands located at 1542 and $1545 \mathrm{~cm}^{-1}$ correspond to the quinone ring $\mathrm{C}-\mathrm{C}$ stretching mode [18].

Medium intensity bands between 1339 and $1370 \mathrm{~cm}^{-1}$ can be assigned to the DMF CN stretching, overlapping with the $\mathrm{CH}$ absorption of lapachol side chain [21]. Bands in the $1276-1275 \mathrm{~cm}^{-1}$ range are attributed by Sawhney and Matta [22] to lapachol C10-O2 (single bond, phenol) stretching modes, but it is not possible to make definitive assignments as there may also appear overlapping in-plane $\mathrm{CC}$ and $\mathrm{CH}$ coupled vibrations $[22,23]$. 
Electronic spectra

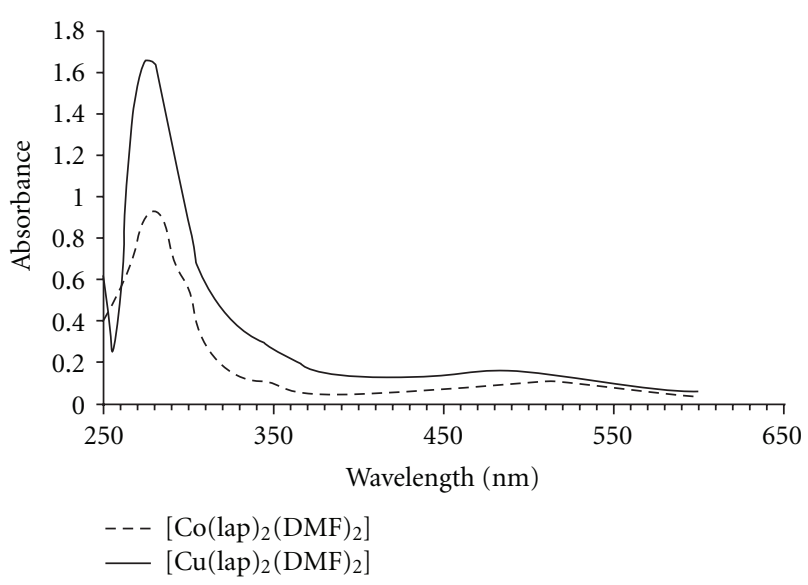

Figure 3

The $\mathrm{M}-\mathrm{O}$ stretching modes are expected in the region from 500 to $200 \mathrm{~cm}^{-1}$, as in acetylacetonates of $\mathrm{Cu}^{2+}$ and $\mathrm{Ni}^{2+}$ where IR bands are reported at 455 and $291 \mathrm{~cm}^{-1}$, and 438 and $271 \mathrm{~cm}^{-1}$, respectively $[24,25]$. Being out of the useful range of our instrument, they will not be discussed any further.

4.3. Electronic Spectra. The electronic spectra of the Co and $\mathrm{Cu}$ complexes (Figure 3) show in the UV strong bands at $280 \mathrm{~nm}(\mathrm{Co})$ and $284 \mathrm{~nm}(\mathrm{Cu})$ and shoulders at 345 and $350 \mathrm{~nm}$, respectively. In the visible region there appear a medium intensity broad band with maximum absorption at $510 \mathrm{~nm}(\mathrm{Co})$ and $490 \mathrm{~nm}(\mathrm{Cu})$ which give rise to the intense dark red color exhibited by the complexes. These bands may be due to the conjugated system mesomeric: $\mathrm{O} 2-\mathrm{C} 10=\mathrm{C} 9$ $\mathrm{C} 8=\mathrm{O} 3 \leftrightarrow \mathrm{O} 2=\mathrm{C} 10-\mathrm{C} 9=\mathrm{C} 8-\mathrm{O} 3$ (p-quinone $\leftrightarrow$ oquinone) [9]. This band could be assigned to a transition $\left(\pi \rightarrow \pi^{*}\right)$ of the quinone carbonyls [25].

The electronic absorption bands of aromatic rings assigned to $\pi \rightarrow \pi^{*}$ transitions are observed at 214 and $231 \mathrm{~nm}$ (benzene ring), $277 \mathrm{~nm}$ (quinone ring), and $340 \mathrm{~nm}$ (benzene ring) [24]. In the electronic spectra of the complexes we observe a sharp and intense band at $238 \mathrm{~nm}$ and weak shoulders at 271 and $341 \mathrm{~nm}$ that could be attributed to those transitions.

4.4. Thermogravimetric (TGA) Analysis. As expected, the thermogravimetric data for both isostructural complexes are very similar to each other. The TGA recording for $\left[\mathrm{Co}(\mathrm{Lap})_{2}(\mathrm{DMF})_{2}\right]$ is shown in Figure 4 . The first step ends at about $250^{\circ} \mathrm{C}$ and has a mass loss of $20.8 \%$ and corresponds to the elimination of two molecules of DMF (theoretical value: $21.2 \%$ ). The second and third steps between $275^{\circ} \mathrm{C}$ and $450^{\circ} \mathrm{C}$ correspond to the oxidation reaction of the lapacholate groups. The total mass loss is $88.6 \%$ while the expected value for the formation of the $\mathrm{Co}_{2} \mathrm{O}_{3}$ is $87.9 \%$ [18].

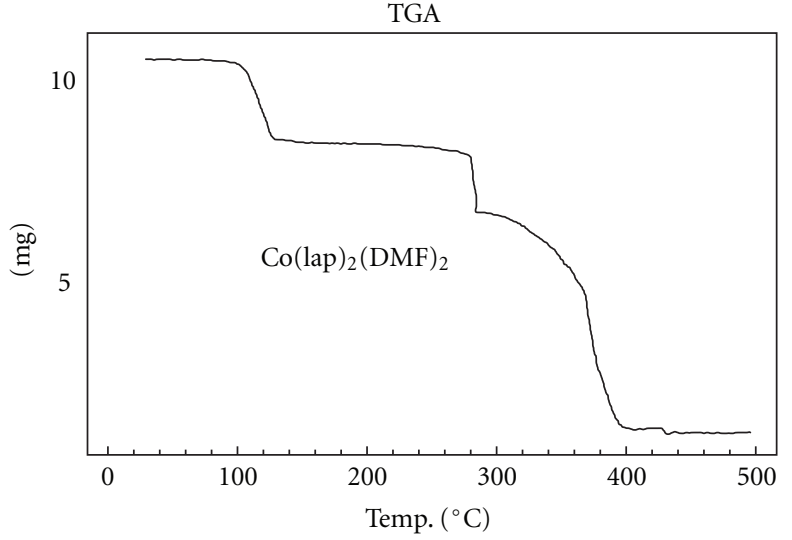

Figure 4

\section{Conclusions}

From the above discussion, we can draw the following main conclusions.

(i) We confirm here the chelating versatility of lapacholate ligand toward transition metal ions, through their phenol and ortho and para carbonyl oxygen atoms, by reporting two new isostructural $\mathrm{M}(\mathrm{Lap})_{2}(\mathrm{DMF})_{2}(\mathrm{M}: \mathrm{Co}, \mathrm{Cu})$ members of an ever growing family of lapacholate-metal complexes. We also demonstrate the ability of DMF molecule (along with other polar solvents like water and ethanol) to complete octahedral binding sites around metal in lapacholate complexes.

(ii) We have determined the vibration structure of the new complexes by assigning most of their modes and characterized common features that relate the isostructural pair to each other and to other members of the lapacholate-metal family of complexes.

(iii) The dark-red color of the complexes can be traced to a strong and broad electronic absorption band centered at about $510 \mathrm{~nm}(\mathrm{Co})$ and $490 \mathrm{~nm}(\mathrm{Cu})$ in the UV-visible spectra which can be assigned to pquinone $\leftrightarrow$ o-quinone mesomerism in the quinonic ring conjugated system. Listings of fractional coordinates and equivalent isotropic displacement parameters of the non-H atoms (Tables S3a, b), full intramolecular bond distances and angles (Tables S4a,b), anisotropic displacement parameters for the non- $\mathrm{H}$ atoms (Tables S5a,b), and hydrogen atoms positions (Tables S6a,b) are provided as Supplementary Material available online at doi:10.1155/2012/973238.

\section{Acknowledgments}

This work was supported by CONICET of Argentina and FAPESP of Brazil. O. E. Piro is a Research fellow of CONICET. This paper is in memory of Professor P. J. Aymonino. 


\section{References}

[1] P. A. L. Ferraz, F. C. De Abreu, A. V. Pinto, V. Glezer, J. Tonholo, and M. O. F. Goulart, "Electrochemical aspects of the reduction of biologically active 2-hydroxy-3-alkyl-1,4naphthoquinones," Journal of Electroanalytical Chemistry, vol. 507, no. 1-2, pp. 275-286, 2001.

[2] M. K. Rafiullah and M. M. Suleiman, "5-Hydroxy lapachol: a cytotoxic agent from Tectona grandis," Phytochemistry, vol. 50, pp. 439-442, 1999.

[3] M. F. Oliveira, T. L. G. Lemos, M. C. De Mattos, T. A. Segundo, G. M. P. Santiago, and R. Braz-Filho, "New enamine derivatives of lapachol and biological activity," Anais da Academia Brasileira de Ciencias, vol. 74, no. 2, pp. 211-221, 2002.

[4] T. A. Annan, C. Peppe, and D .G. Tuck, "The direct electrochemical synthesis of $\mathrm{d}^{10}$ metal ion derivatives of some anionic bidentate oxygen donors," Canadian Journal of Chemistry, vol. 68, pp. 423-430, 1990.

[5] T. A. Annan, C. Peppe, and D. G. Tuck, "The direct electrochemical synthesis of some metal derivatives of 3-hydroxy-2methyl-4-pyrone," Canadian Journal of Chemistry, vol. 68, pp. 1598-1605, 1990.

[6] K. H. Thompson, C. A. Barta, and C. Orvig, "Metal complexes of maltol and close analogues in medicinal inorganic chemistry," Chemical Society Reviews, vol. 35, no. 6, pp. 545-556, 2006.

[7] F. Caruso, M. A. Martínez, M. Rossi, A. Goldberg, M. E. C. Villalba, and P. J. Aymonino, "Crystal and molecular structure of manganese(II) lapacholate, a novel polymeric species undergoing temperature-reversible metal to ligand electron transfer," Inorganic Chemistry, vol. 48, no. 8, pp. 3529-3534, 2009.

[8] R. Hernández-Molina, I. Kalinina, P. Esparza et al., "Complexes of $\mathrm{Co}(\mathrm{II}), \mathrm{Ni}(\mathrm{II})$ and $\mathrm{Cu}(\mathrm{II})$ with lapachol," Polyhedron, vol. 26, no. 17, pp. 4860-4864, 2007.

[9] M. A. Martínez, M. C. L. De Jiménez, E. E. Castellano, O. E. Piro, and P. J. Aymonino, "Synthesis, structure and properties of a zinc(II) complex with the lapacholate anion and ethanol as ligands," Journal of Coordination Chemistry, vol. 56, no. 9, pp. 803-816, 2003.

[10] R. A. Farfán, J. A. Espíndola, M. A. Martínez, O. E. Piro, and P. J. Aymonino, "Synthesis and crystal structure of a new lapacholate complex with nickel(II), $\left[\mathrm{Ni}(\mathrm{Lap})_{2}(\mathrm{DMF})\left(\mathrm{H}_{2} \mathrm{O}\right)\right]$," Journal of Coordination Chemistry, vol. 62, no. 23, pp. 37383744, 2009.

[11] Enraf-Nonius, COLLECT. Nonius BV, Delft, The Netherlands, 1997-2000.

[12] Z. Otwinowski and W. Minor, "Processing of X-ray diffraction data collected in oscillation mode," in Methods in Enzymology, C. W. Carter Jr. and R. M. Sweet, Eds., vol. 276, pp. 307-326, Academic Press, New York, NY, USA, 1997.

[13] A. L. Spek, PLATON, A Multipurpose Crystallographic Tool, Utrecht University, Utrecht, The Netherlands, 1998.

[14] G. M. Sheldrick, SHELXS-97. Program for Crystal Structure Resolution, University of Göttingen, Göttingen, Germany, 1997.

[15] G. M. Sheldrick, SHELXS-97. Program for Crystal Structure Analysis, University of Göttingen, Göttingen, Germany, 1997.

[16] C. K. Johnson, "ORTEP-II. A Fortran Thermal-Ellipsoid Plot Program,” Tech. Rep. ORNL-5318, Oak Ridge National Laboratory, Oak Ridge, Tenn, USA, 1976.
[17] E. H. De Oliveira, G. E. A. Medeiros, C. Peppe, M. A. Brown, and D. G. Tuck, "The direct electrochemical synthesis of some metal derivatives of lapachol," Canadian Journal of Chemistry, vol. 75, no. 5, pp. 499-506, 1997.

[18] M. A. Martínez, M. C. L. de Jiménez, E. E. Castellano, O. E. Piro, and P. J. Aymonino, "Two isostructural complexes of $\mathrm{Co}(\mathrm{II})$ and $\mathrm{Zn}$ (II) with lapacholate, dimethylformamide and water, $\left[\mathrm{M}(\mathrm{Lap})_{2}(\mathrm{DMF})\left(\mathrm{H}_{2} \mathrm{O}\right)\right]$," Journal of the Argentine Chemical Society, vol. 93, no. 4-6, pp. 183-193, 2008.

[19] S. Da Guia Mello Portugal, J. O. Machuca Herrero, and E. Mark Brinn, "Anomalous electronic absorption in lapacholialcohol solutions," Bulletin of the Chemical Society of Japan, vol. 70, pp. 2071-2076, 1997.

[20] J. Wang, X. Duan, and J. Niu, "Synthesis and crystal structure of a 2D network polyoxometalate-based complex $\left[\mathrm{Ba}_{2}(\mathrm{DMF})_{5}\left(\mathrm{H}_{2} \mathrm{O}\right)_{5}\right] \mathrm{SiW}_{12} \mathrm{O}_{40} \cdot \mathrm{DMF} \cdot \mathrm{H}_{2} \mathrm{O}_{n}$," Journal of Molecular Structure, vol. 693, no. 1-3, pp. 187-191, 2004.

[21] R. A. Farfán, J. R. Molina, E. Otavianelli, and J. A. Espíndola, "Asignación de Bandas de Infrarrojo del Lapachol mediante Estudios Comparativos Teóricos y Experimentales," Información tecnológica, vol. 17, pp. 63-66, 2006.

[22] S. S. Sawhney and S. D. Matta, "pH-metric, Spectral, Magnetic and Thermal Investigation on Ni-2-hydroxy- 3-(3-methyl-2butenyl)-1,4-naphthoquinone (Lapachol) Complex," Journal of the Indian Chemical Society, vol. 57, no. 5, pp. 497-499, 1980.

[23] H. Rostkowska, M. J. Nowak, L. Lapinski, and L. Adamowicz, "Molecular structure and infrared spectra of 2-hydroxy-1,4naphthoquinone; Experimental matrix isolation and theoretical Hartree-Fock and post Hartree-Fock study," Spectrochimica Acta Part A, vol. 54, no. 8, pp. 1091-1103, 1998.

[24] I. Singh, R. T. Ogata, R. E. Moore, C. W. J. Chang, and P. J. Scheuer, "Electronic spectra of substituted naphthoquinones," Tetrahedron, vol. 24, no. 18, pp. 6053-6073, 1968.

[25] R. C. Agarwal, B. Rashmi, and R. L. Prasad, "Sinthesis and characterization of some $3 \mathrm{~d}$ metal (II) ternary complexes of acetylacetone and 1-nitroso-2-Naphtol," Synthesis and Reactivity in Inorganic and Metal-Organic Chemistry, vol. 14, no. 2, pp. 171-184, 1984. 


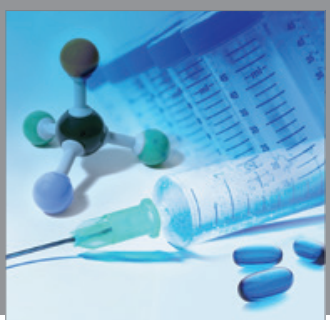

International Journal of

Medicinal Chemistry

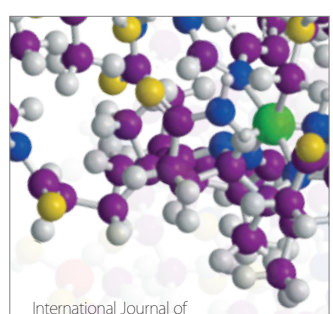

Carbohydrate Chemistry

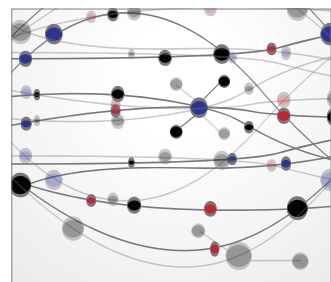

The Scientific World Journal
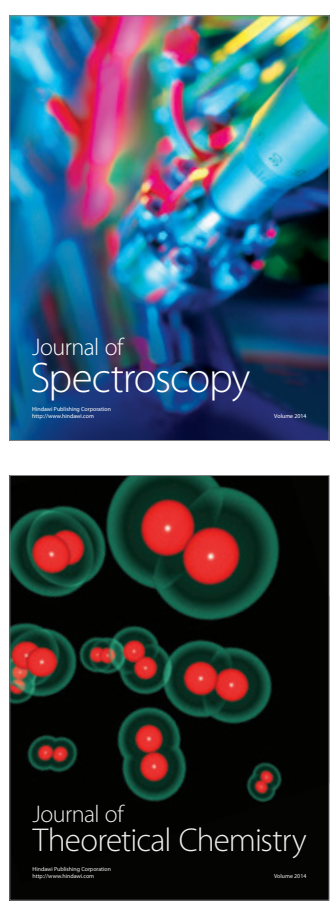
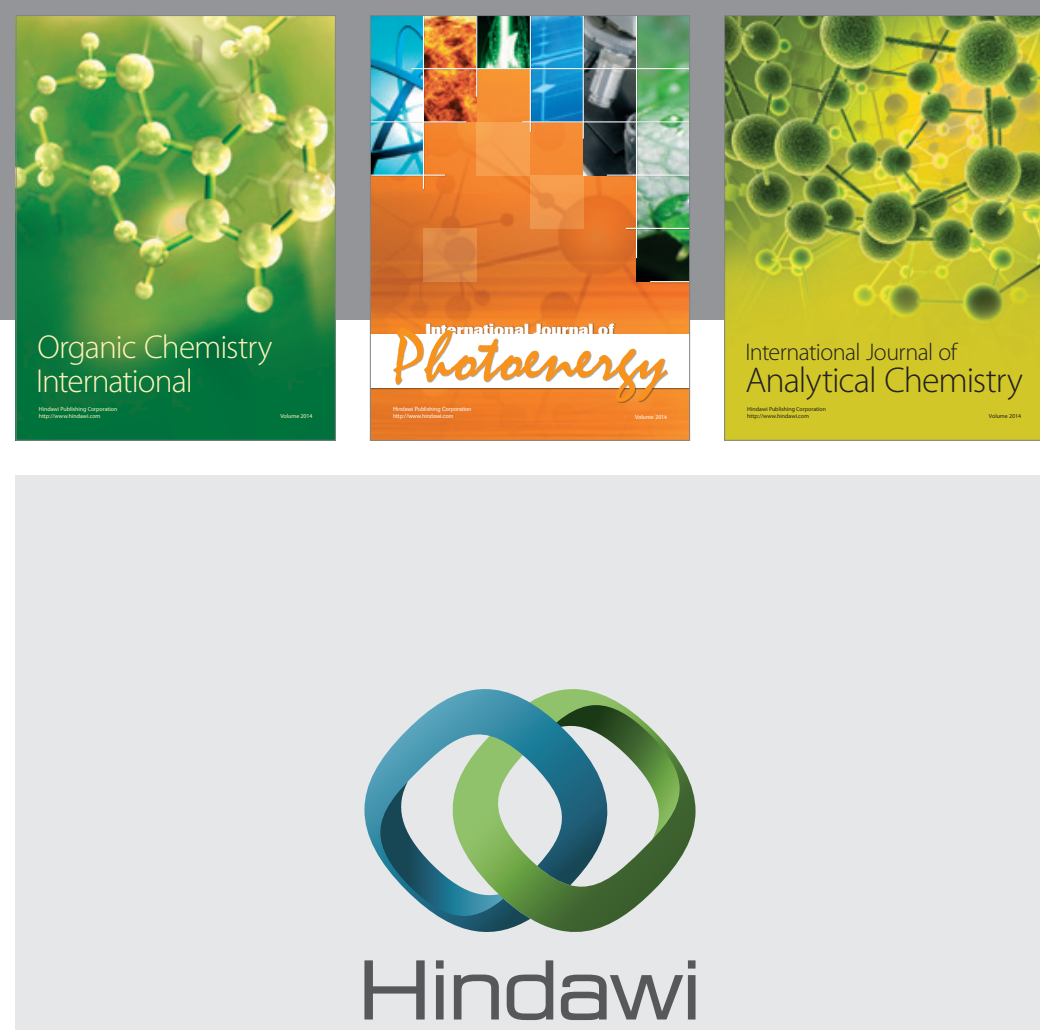

Submit your manuscripts at

http://www.hindawi.com
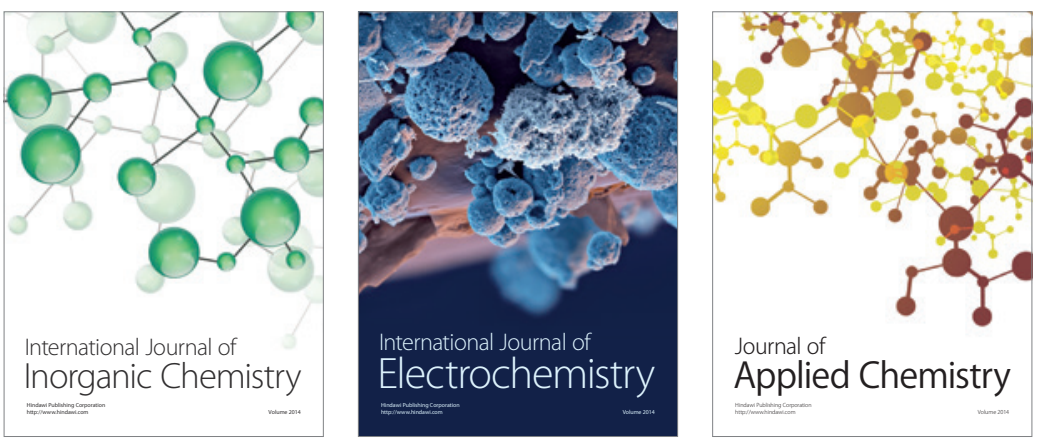

Journal of

Applied Chemistry
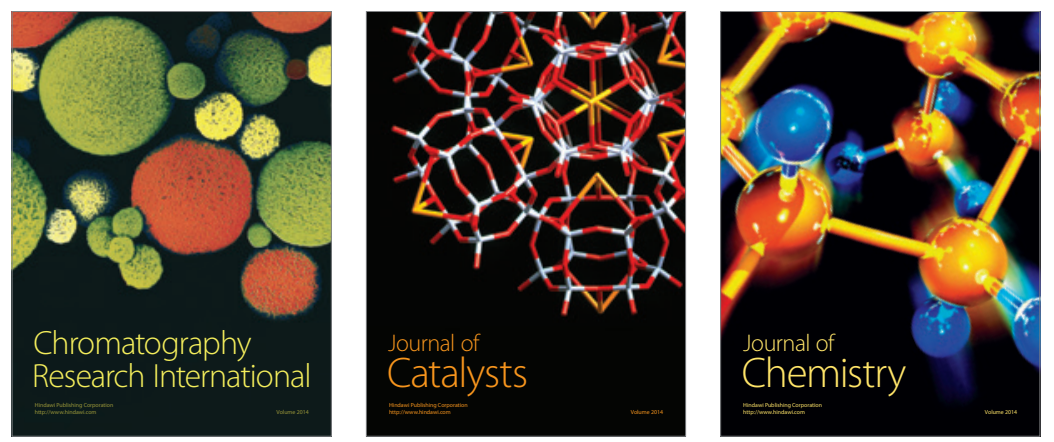
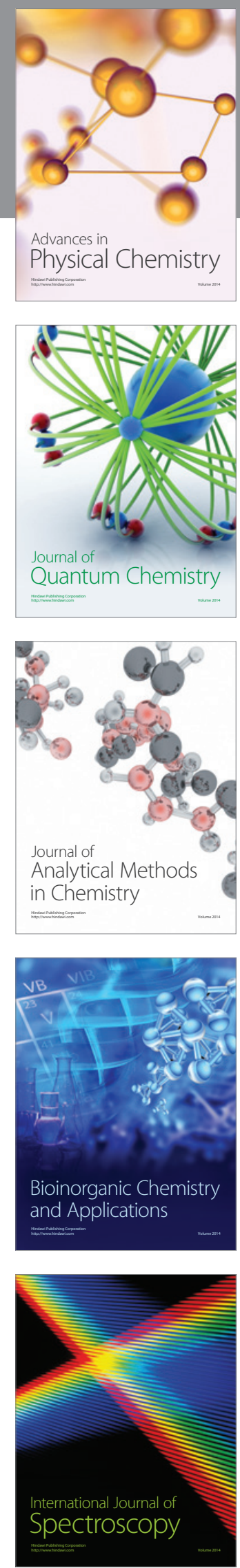